\title{
A PPD allergia jelentősége a mindennapi gyakorlatban
}

\section{The importance of PPD allergy in everyday practice}

\author{
FÁBOS BEÁTA DR., BATTYÁNI ZITA DR. \\ Kaposi Mór Oktató Kórház Bőrgyógyászati Osztály, Kaposvár
}

\section{ÖSSZEFOGLALÁS}

Az egyes korok allergén expozícióját különbözö tényezók befolyásolták, és befolyásolják. A szenzibilizáció tekintetében fontos szerepe van az éppen aktuális divat trendeknek, a gyors ütemben haladó technológiai fejlesztéseknek, melyek sokszor túlhaladják diagnosztikai lehetôségeinket, és folyamatos kihívás az újabb allergének megjelenésével. Befolyásoló tényezók a hivatalos szabályozások, helyi szokások, munkafeltételek alakulása, melyek kapcsán az egyén különbözö környezeti allergénekkel kerül kapcsolatba. A PPD egy para-állású vegyület, mely az oxidativ festékek csoportjába tartozik, és a levegö oxigén tartalmának hatására aktív quininonedimin derivátummá alakul. Allergenitása már régóta ismert, viszont az új expozíciós források fokozzák a szenzibilizáció kockázatát, megteremtve annak lehetőségét, hogy egyre gyakoribbá váljon a kontakt allergének között, ez vezetett arra, hogy 2006-ban az Amerikai Kontakt Dermatitis Társaság az év allergénjének választotta (1). A cikk szerzői KMOK Börgyógyászatán végzett 5 éves (2006-2010) standard epikután tesztelés eredményét áttekintve vizsgálják a PPD szerepét, és helyét a többi allergén között. Saját beteganyagukon keresztül mutatják be a PPD allergia okozta börtünetek sokszínüségét, mely az enyhe, bizonytalan reakcióktól az egészen kifejezett, súlyos allergiás reakciókig terjed. Rávilágítanak a szerteágazó keresztreakciókra, és az azo-festékek kapcsán a textil allergia lehetőségére.

\section{Kulcsszavak:}

PPD-oxidatív festék - para-állású vegyület kontakt allergén - standard epikután teszt azo-festékek

\section{SUMMARY}

The allergen exposition in different times has been influenced by different factors. Fashion trends and rapidly developing technology, play an important role in sensibility, this process often exceeds our diagnostic possibilities and presents a continuous challenge with the appearance of new allergens. Official policies, local guidelines and workplace condition are influencing factors, as they determine what different environmental allergens we encounter.

$P P D$ is a para-positioned compound in the group of oxidative dye which can be transformed to active derivate quininonedimine by the air oxygen. The allergic effect of PPD is known for a long time, but due to new exposition sources, the risk of sensibilisation has risen, enabling it to occur more often amongst contact allergens. This lead for PPD to become the allergene of 2006 by the American Contact Dermatitis Group (1).

In this article the role of PPD and its incidence amongst other allergens were investigated in a retrospective examination of results from standard patch testing at the Dermatology Department of the Kaposi Mor Teaching Hospital in Kaposvár between 2006-2010. The authors of this article demonstrate the diversity of symptoms caused by PPD from mild skin signs to severe allergic reaction through their data. They highlight the wide range of crossreactions and the possibilites of azo-dyes related textile allergy.

\section{Key words: \\ PPD - oxydative dye - para- positioned compound - contact allergen - standard patch testing - azo-dyes}

Az emberiség ősi időktől fogva meglévő tulajdonsága, hogy szebbé, mássá szeretné tenni magát, melyhez többek között különböző festékeket, ékszereket használ. Az ipar fejlődése is egyre több „mesterséges” anyagot állít elő, amit a mindennapokban a munka könnyítése, szépészeti célból, vagy csak a mindennapi használat során alkalmazunk. A kibővült kínálat eredményeként egyre szélesebb körben alakul ki allergia. Az allergiát kiváltó anyagok száma már megszámlálhatatlan. A kozmetikai ipar az elsődleges felhasználó és allergiát okozó ágazat. Az allergiát kiváltó anyagok közül kiemelkedő előretörés figyelhető meg a para-pheniléndiamin (PPD) vonatkozásában is. A PPD egy para-állású vegyület, mely az oxidatív festékek csoportjába tartozik, és a le-

Levelező szerző: Dr. Fábos Beáta,Kaposi Mór Oktató Kórház Bőrgyógyászati Osztály Kaposvár e-mail: fabosb@t-online.hu 
vegő oxigén tartalmának hatására aktív quininonedimin derivátummá alakul. Korábban elsősorban, mint a fekete gumi egyik összetevőjét ismertük, és főként ilyen jellegû munkahelyeken, foglalkozási allergénként fordult elő nagyobb számban. Napjainkban, elsôsorban a kozmetikai elterjedése miatt, egyre nagyobb szerepet játszik a kontakt allergiás reakciók kiváltásában, nem véletlen, hogy 2006-ban az Amerikai Kontakt Dermatitis Társaság az év allergénjének választotta (1). Jelen munkánkban célul tûztük ki saját beteganyagunkban a PPD előfordulásának vizsgálatát.

\section{Anyag és módszer}

A Somogy Megyei Kaposi Mór Oktató Kórház Bőrgyógyászati osztályán az allergiás betegek kivizsgálása során rendszeresen végzünk epikután vizsgálatokat, standard, fodrászati, fogászati és szteroid sorral, valamint atopy patch tesztet. 2006 és 2010 között végzett epikután tesztelt beteganyag retrospektív vizsgálatát végeztük el, a PPD allergia előfordulásának felmérése céljából. A bőrgyógyászati osztályon a standard (magyar) epikután tesztsort használtuk, melyben a PPD 1\% koncentrációban, vazelin alapanyagban található. A vizsgálat során 48 órás expozíciót követően 48, 72, 96, és 168 óra után történt leolvasás, a reakciók értékelését standard módon, az adott válaszreakció erőssége alapján (+: gyengén pozitív, ++: mérsékelten pozitív,+++: erősen pozitív) végeztük.

\section{Eredmények}

$\mathrm{Az} 5$ év alatt Intézményünkben összesen az elvégzett standard epikután tesztvizsgálatok száma 1254, az évek szerinti megoszlást az 1. táblázat mutatja. A vizsgált egyének nemek szerinti megoszlása egyértelmúen nôi dominanciát mutat, $75,5 \%$ volt a nők aránya. A leggyakoribb allergének évek szerinti megoszlását tüntettük fel 2 . táblázatban. Kiemelendő, hogy a PPD 2009 kivételével minden évben szerepel a listában, és évrôl évre előkelőbb helyet foglal el. A vizsgált 35 allergén között 2008-ban a 8., 2010-ben a 6 . helyen szerepelt. A legmagasabb előfordulási gyakoriságot 2010ben észleltuik 9,6\%-kal (3. táblázat), mely az előző évekhez képest növekedést mutatott. Ha a vizsgált 5 év átlagában nézzük a PPD allergia előfordulását, $5,9 \%$-os gyakoriságot találtunk, mely valamivel alacsonyabb, mint az Észak Amerikai Kontakt Dermatitis Munkacsoport 2005-2006 között észlelt 6,8\%-os gyakorisága (2). Magasabb előfordulást csak krónikus aktinikus dermatitisben találtak 7,7\%-ot (3). A többi allergén vonatkozásában, ha az 5 év alatt pozitív eredménnyel tesztelt betegek top 10 allergénjeit áttekintjük, akkor kitúnik a nikkel szulfát vezető szerepe $(21,85 \%)$, mely a vizsgált években egységesen az első helyen szerepel, és ez tükrözi a nikkel nemzetközileg is elfoglalt első helyét, mely széles körben való használatának köszönhető. A farmer szegecsektől a divatékszerekig, a gyógyászatban használt sebészeti eszközök, orvosi klippektől a pénz érmékig, de bizonyos élelmiszerek, mint a csokoládé, szója és a spárga is nagyobb mennyiségben tartalmazza. Az ezt követô allergének sorrendisége már évente változik, de a nikkelt 5 év átlagában az illat keverék I, kobalt-klorid, perubalzsam, holzter mix, thiomersal, formaldehyd, higany II- amidoklorid, PPD, higany-klorid követi a gyakoriság sorrendjében.

A PPD allergia miatt észlelt saját eseteink jól illusztrálják a festék allergia leggyakoribb klinikai formáit.

2010-ben észleltük azt a 12 éves leányt, aki balatoni nyaralás kapcsán kért a szüleitôl egy ideiglenes tetoválást, melyet ártalmatlannak gondolnánk. Sajnos az ő esetében a tetoválást követően hyperergiás allergiás reakció lépett fel, mely hegesedés hátrahagyásával gyógyult, és egy életre szóló nyomot hagyott a gyermek bőrén (1., 2 . ábra).

\begin{tabular}{|l|l|l|l|l|l|l|}
\hline évek & 2006 & 2007 & 2008 & 2009 & 2010 & összes \\
\hline tesztelt $(\mathrm{n})$ & 324 & 225 & 254 & 224 & 227 & 1254 \\
\hline férfi & 77 & 62 & 60 & 58 & 50 & 307 \\
\hline nő & $247(76 \%)$ & $163(72 \%)$ & $194(76 \%)$ & $166(74 \%)$ & $177(78 \%)$ & $947(75,5 \%)$ \\
\hline
\end{tabular}

1. táblázat

A standard epikután tesztelések száma 2006-2010 között, nemek szerinti megoszlása

\begin{tabular}{|c|c|c|c|c|c|}
\hline évek & & & & & \\
\hline \begin{tabular}{|l|} 
előfordulási \\
gyakoriság
\end{tabular} & 2006 & 2007 & 2008 & 2009 & 2010 \\
\hline 1 & nikkel (86) & nikkel (56) & nikkel (37) & nikkel (39) & nikkel (55) \\
\hline 2 & kobalt (36) & illat- I (21) & holzter (33) & illat -I (16) & thiomers.(16) \\
\hline 3 & formald.(21) & holzter (20) & illat- I (27) & perubalzs(12) & silberam.(12) \\
\hline 4 & illat- I (17) & thiomers.(20) & perubalzs(22) & illat- II (11) & kobalt (11) \\
\hline 5 & perubalzs(17) & kobalt (19) & lanolin (15) & holzter (8) & silberchl.(11) \\
\hline 6 & thiomers.(15) & formald.(16) & kobalt (13) & kobalt (8) & PPD (9) \\
\hline 7 & propolis (8) & perubalzs(16) & formald.(12) & propylengl(8) & holzter (9) \\
\hline 8 & króm (8) & silberam (14) & PPD (11) & thiomers.(7) & perubalzs (7) \\
\hline 9 & neomycin (8) & silberchl.(12) & neomyc.(11) & budesonid (6) & katon CG (7) \\
\hline 10 & PPD (7) & PPD (9) & thiuram (8) & silberam (6) & illat-I (7) \\
\hline
\end{tabular}

2. táblázat

A 10 leggyakoribb allergén 2006-2010 között

\begin{tabular}{|l|l|l|l|l|l|}
\hline évek & 2006 & 2007 & 2008 & 2009 & 2010 \\
\hline gyakoriság & $4,3 \%$ & $7,9 \%$ & $7,4 \%$ & $4,7 \%$ & $9,7 \%$ \\
\hline
\end{tabular}

3. táblázat

PPD előfordulási gyakorisága 


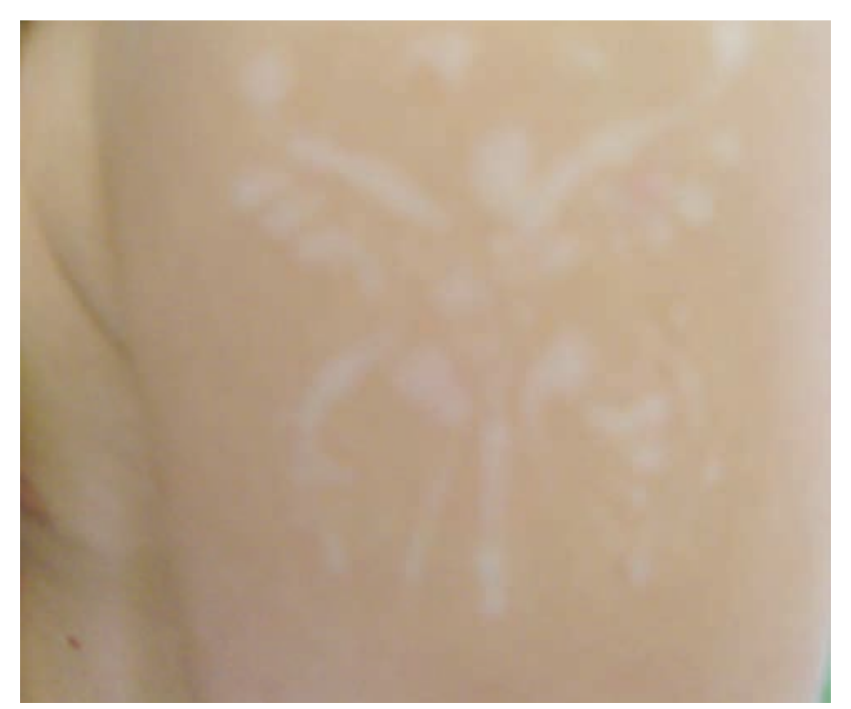

1. ábra

Henna tetoválást követően kialakult hólyagos, allergiás bőrreakció után visszamaradt hegesedés

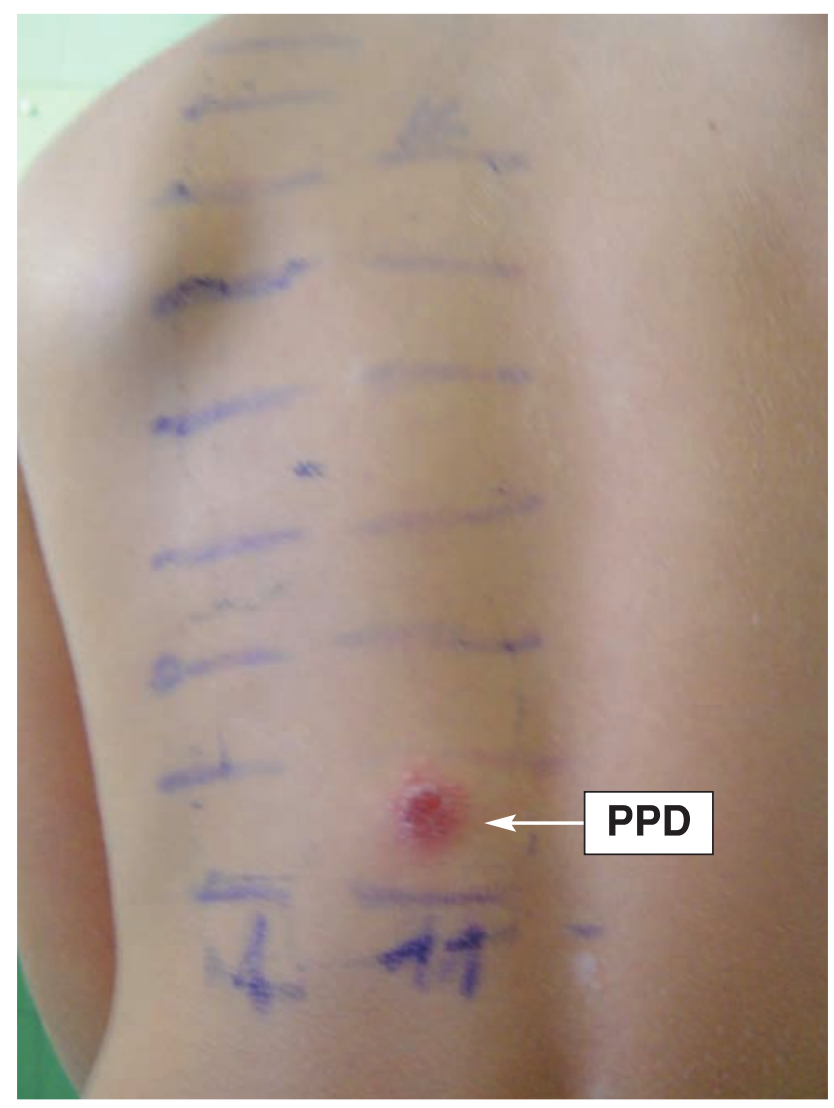

2. ábra

Henna tetoválás mellett epicutan próbával igazolt PPD szenzibilizáció

2010-ben osztályunkon észleltünk súlyos allergiás reakciót egy 25 éves nôbetegnél, kinek korábbi betegsége közül az epilepsziát lehet megemlíteni, mely miatt Keprát ${ }^{\circledR}$ szedett. 2010 június 15.-én császármetszéssel kislánya született, ezt követően egy hónappal haját befestette. Már a hajfestés napján este fejbőre viszketett, s később kifejezett fejbőrnedvezés, arcduzzanat miatt fordult a sürgőssé-



\section{3. ábra}

$\mathrm{Az}$ arc kifejezett duzzanata

gi osztályra, ahonnan ambulanciánkra irányították. Észlelésekor a homlokon, jobb arcfélen, a fülkagylón kifejezett duzzanat (3. ábra) egész hajas fejbốrre terjedôen macerá-

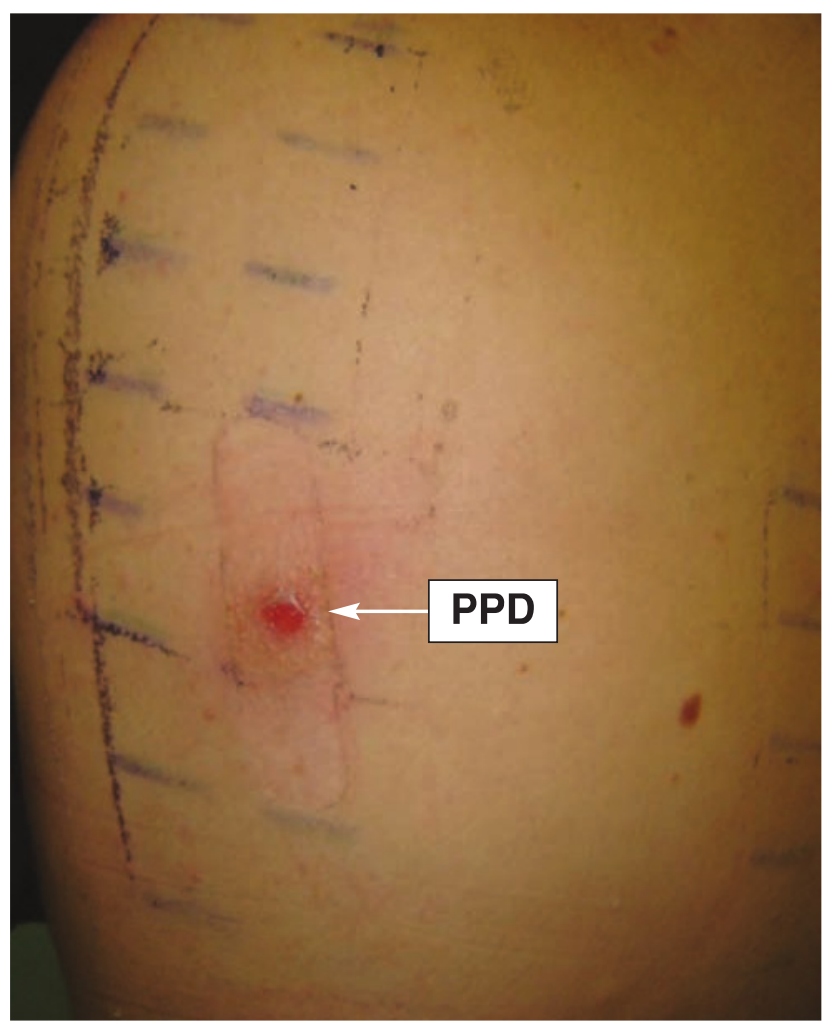

4. ábra

Standard epikután tesztelés 128 órában történő észlelés PPD érzékenység igazolódott 


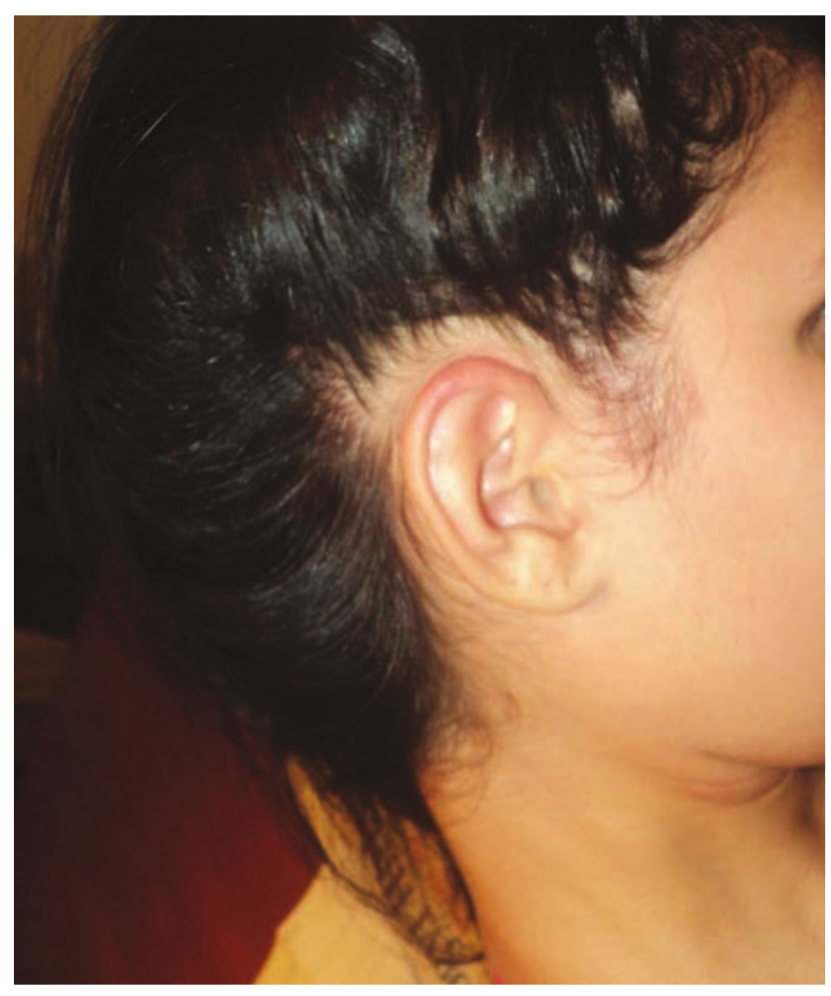

5. ábra

Fülkagyló széli részén seropapulák

ció, nedvezés, seropapulák helyezkedtek el. Kifejezett kontakt allergiás tünet miatt $1 \mathrm{mg} / \mathrm{tskg}$ metylprednisolon és parenterális antihisztamin terápiában részesült, mely 5 nappal a tünetek javulását követően fokozatos leépítésre került. 2010 szeptemberben standard, és fodrász sorral elvégzett tesztelés során 20 percben: negatív, 48,72, 96,128 órában PPD +++ (4. ábra), o-Nitro-p-phenylendiamin ++, toluylendiaminsulfat, 3-aminophenol 1\%, 4-aminophenol $1 \%+++$ pozitivitást találtunk.

2012-ben észleltük egy fiatal nőbetegünknél a hajfestést követően kialakult típusos bőrtüneteket, itt a fülkagyló széli részén, tarkótájékon mutatkoztak erythemás alapon seropa-



6. ábra

Hajas fejbőrön maceráció, nedvezés pulák (5. ábra), valamint fejbőr exudáció (6. ábra) lépett fel duzzanat nélkül. Ebben az esetben per os antihisztamin, és helyi kortikoszteroidok adása mellett a tünetek regrediáltak. Tesztelése során 48, 72, 96, 128 órában PPD+++, o-Nitro-p-phenylendiamin++, toluylendiaminsulfat, 3-aminophenol 1\%, 4-aminophenol 1\% ++ pozitivitást találtunk.

\section{Megbeszélés}

A para-phenylendiamin (PPD) allergia gyakorisága az utóbbi időben növekszik, a szenzibilizálódáshoz számos új divat járul hozzá, mint az ideiglenes tetoválás, a hajfestési szokások változása valamint bizonyos foglalkozások: fodrász, kozmetikus, ahol fokozott az expozíció. A PPD egy olyan vegyi anyag, mely a mindennapi gyakorlatban széles körben megtalálható, tartós hajfesték, textil-, szőrme festékek, sötét színú kozmetikumok, fénymásolónyomdafestékek, fényképészeti előhívók, litográfiai lemezek, fekete gumi, benzin, olaj egyik alkotóeleme, így nem meglepő az egyre növekvő érzékenység. A PPD tartós, vagy oxidatív hajfestékek állandó komponense, és Nyugat-Európában az 1880-as években vezették be (4). Magas allergenitása miatt használata 1906-tól a 1980-as évekig Nyugat-Európa egyes országaiban tiltott volt, majd ezt követően az EU tagállamaiban ismételten és egyre szélesebb körben elterjedt

A PPD szenzibilizáció elsődleges forrása a hajfesték, amely festett hajú személyeken, ill. a fodrászok körében vált ki allergiás reakciót. Az őszülő korosztály női és férfi tagjainak természetes igénye az eredeti hajszín visszaállítása, mely a festékipar számára hatalmas piaci lehetőséggel bír. De nem csak az őszülők alkalmaznak hajfestést, egyre fiatalabb korosztályok női és férfi tagjai is nagyobb arányban változtatják meg eredeti hajszínüket. Az életkor csökkenése fokozza a PPD-vel szembeni szenzibilizáció kockázatát, és egyre inkább számítani kell a PPD-vel keresztreagáló festékkomponensek megjelenésére. A hajfestéken kívül alkalmazzák textíliák, szőrmék festésére, így textil festék dermatitis kiváltásában is szerepe lehet. A gumi gyártás során antioxidansként használt az n-isopropyln-phenyl-p-phenylendiamin, mely egyes munkahelyen fekete és szürke gumi ruházat formájában PPD szenzibilizáció forrása lehet. Elsőként foglalkozási allergénként került leírásra a fekete gumi kapcsán kőmúveseken, kohászokon, valamint fogtechnikusok és paracetamollal érintkezó vegyipari dolgozók esetében. Szenzibilizációbeli eltérések nem csak foglalkozásonként, de egyes etnikai csoportok között is megfigyelhetők. A fekete lakosság körében nagyobb előfordulási gyakoriság figyelhető meg, mint a fehér lakosság körében, melyet először Fisher észlelt, és több nagyobb betegszámú vizsgálat is megerôsítette a megfigyelést (5). Ennek oka alapulhat valódi genetikai különbségeken, de adódhat abból is, hogy sötétebb árnyalatú festékeket alkalmaznak, melyben magasabb a PPD koncentrációja (6).

\section{Hajfestés, hajfesték allergének}

A hajfestékekben lévő festékanyagok kémiai szerkezetétôl függ, hogy a festék milyen tartós, milyen mélységé- 
ben hatol a hajszál keratinjába, vagy csak a felülethez kötôdik. Eszerint a festékeket 3 csoportba sorolhatjuk, az oxidatív vagy tartós hajfestékek, a direkt vagy féltartós festékek, az ideiglenes festékek vagy tónusöblítők.

Az oxidatív vagy tartós festékek, festék féltermékeket tartalmaznak, ami azt jelenti, hogy a festék féltermék egyes molekuláinak oxidációja révén létrejövő kapcsolódásából alakul ki a festék pigment. Ezért minden tartós festéket oxidáló szerrel (előhívó) kell kikeverni, mivel a levegó oxigénje csak a felületen hoz létre festőanyagot, a hajban nem. A legtöbb festékanyagban a legfontosabb festék féltermék a PPD (cc:6\%), és a toluen-2,5-diamin (cc:10\%). A színezés szempontjából különleges jelentőségûek a kapcsoló komponensek, melyek a festék féltermékkel kapcsolódva más színhatású festéket képez, ezért ezeket a vegyületeket színmódosítóknak is nevezik. Erre használják a resorcinolt, m-aminophenolt, 2,4-diaminophenoxyethanolt, 1-naphtolt. Lúgosító szerként ammónium-hidroxidot, ammónium sókat, monoethanolamint, aminomethylpropanolt használnak, mely elősegíti a festék keratinba történő bejutását. Kondicionáló anyagokat (lanolin, glycerin), konzerválókat, és illat anyagokat is tartalmaz, hogy elnyomja az ammónia kellemetlen szagát. Ezek a festékek képesek a haj színének teljes megváltoztatására, illetve a teljes ősz hajszálak fedésére.

A direkt vagy féltartós festékek alacsony molekulasúlyú kémiai festékeket (nitrophenylendiamin, nitro-aminophenol, azo-festék) tartalmaznak, melyek a haj cuticuláján áthatol, a cortexen viszont csak részben, a samponnak kissé ellenáll, így akár több hónapon keresztül tarthatja a színét, és a színmélységet is jelentősen megváltoztatja. Kis mértékű őszülés esetén az ősz hajszálak természetes színének visszaadására képesek.

Az ideiglenes festékek vagy tónusöblítook direkt színezó anyagokat, nagyobb molekulákat tartalmaznak, melyek nem hatolnak át a cuticulán, néhány hajmosás után kimoshatóak, ezek arra használhatók, hogy felfrissítsék a haj természetes színét, vagy divatosan árnyalják pl. pirosra, lilára, aranyra.

A hajfestékekben regisztrált potenciális allergének száma 300-ra tehető, ezek közül 28 azoknak a festékallergéneknek a száma, mely a közepes-, erősen szenzibilizáló csoportba sorolható. A többi allergén gyenge, ill. extrém gyengén allergizáló vegyület.

Az elhangzottakból látható, hogy a PPD-nek közvetlenül, vagy keresztreakció formájában szerepe van az allergia kialakulásában.

\section{Henna tetoválás}

Új szenzibilizációs forrásnak tekinthetjük az ideiglenes hennatetoválást, mely az arab kultúrában régi múltra tekint vissza, a nyugati országokban viszont a testfestés, és a gyerekek körében a hennatetoválás igen népszerú, és a mai kor hozománya. A henna növényi eredetû, barnásvörös színtónusú, gyenge festék, színárnyalatának mélyítésére használják a PPD-t változó koncentrációban $(0,4-$ $29,5 \%$ ), egyes esetekben még a hajfestéknél is nagyobb töménységben. Számos közlemény számol be fiatal gye- rekek százairól, akik enyhe ekzemától, a hegesedéssel, hypopigmentáció hátrahagyásával járó hólyagos reakcióval reagáltak a veszélytelennek gondolt ideiglenes tetoválást követően. Az így kialakult szenzibilizáció is egy életre szóló, és a jövőben számolniuk kell náluk a tartós hajfestékre, gumi kemikáliákra, tintára (7) és a keresztreagáló gyógyszerekre adott allergiás reakciókra (8).

PPD-vel szembeni kontakt allergia esetén a további keresztreakció előfordulhat a ruhában lévő azo-festékek következtében, mely dermatitist eredményezhet. Ennek valódi gyakorisága nem ismert, Ryberg 1,5\%-ban tudta kimutatni Svédországban végzett vizsgálata alapján (9). Sajnos a klinikai kép nem egyértelmú, a betegek nem gondolnak a ruha szerepére, így aluldiagnosztizált marad. Endogén hajlamosító tényezők között szerepel a női nem, idősebb életkor, korábbi gyerekkori ekzema. Külsô tényezők közül a szúk, testhez simuló ruhaviselet, a szintetikus anyagok, izzadás, melyek szerepet játszanak a ruha által kiváltott allergiás reakcióban. A textil allergia kimutatására felmerült egy azo-festék mix stantard sorba történő felvételének lehetősége, de az erre irányuló vizsgálat eredménye azt mutatta, hogy a PPD jó screening allergén (10).

\section{A PPD kereszt allergiái}

A keresztallergiák kapcsán elsősorban az egyéb oxidatív festékeket, anilin és azo-festékeket kell megemlíteni, mint a diszperz narancs 3, de ezen kívül említést kell tennünk azokról a gyógyszerekről is, melyek allergiás tüneteket okozhatnak $(11,12)$. Para-aminosalicylsav észter, lokál anesztetikumok, szulfon származékok (antibiotikum, thiazidok, antidiabetikumok) a legjelentősebbek. Meg kell említeni, mint kereszt allergént a parabent, anthraquinont, valamint több közlemény foglalkozik a kevésbé ismert sesquiterpene lacton mix szerepével (13), mely viszonylag ritkán ad keresztreakciót a PPD-vel, a bőrben végbemenó eltérô genetikai metabolizmusokból adódóan (14).

Saját anyagunkban is az irodalomnak megfelelően a PPD szenzibilizáció jelentős és folyamatos növekedését észleltük. A nők nagyarányú előfordulása miatt a hajfesték oki szerepe feltételezhetô.

A hajfestékek okozta allergia időnként diagnosztikus nehézséget is jelenthet. A PPD allergia esetén a hajfestést követően leggyakrabban akut ekzemás reakció jelentkezik a hajas fejbőr széli részén, tarkótájékon és a fülkagylón. Érintheti a szemhéjat is, mely periódikus szemhéj duzzanat képében nyilvánul meg. A fejbőr lehet megkímélt, de súlyosabb esetben az is érintett, a bőr duzzanata, exudációja lép fel, valamint generalizáltan is jelentkezhetnek bőrtünetek. IgE-mediálta kontakt urticaria, anaphylaxiás reakciót is leírtak festékallergia következtében $(15,16)$, valamint lymphomatoid reakciókat (17).

Jelen közleményünkkel szeretnénk felhívni a figyelmet a minden napi gyakorlatban egyre szélesebb körben elterjedő PPD allergiára, mely számos kiváltó expozíció következtében alakulhat ki, és a részletes anamnézis felvétel, a gondos fizikális vizsgálat és az orvos „ébersége” alapján felismerhető. Az egyre fiatalabb életkorban elkezdett, otthon, nem szakember által végzett hajfestésnek egyre nagyobb szere- 
pe lehet a szenzibilizáció kialakulásának. Prevencióként már forgalomban vannak a „PPD mentes tartós, és féltartós festékek", melyek para-toluendiamin szulfátot tartalmaznak, azonban ezek is csak a PPD allergiások felének jelentenek megoldást, Scheman közleménye alapján 57\%-ban meglévő keresztallergia miatt (18).

\section{IRODALOM}

1. Vincent A., DeLeo V. A.: Contact allergen of the year: pPhenylenediamine. American Contact Dermatitis Society Dermatitis (2006) 17 (2), 53-55. 2006.

2. Zug K. A., Warshaw E. M., Fowler J. F. Jr: Patch-test results of the North American Contact Dermatitis Group 2005-2006. Dermatitis (2009) 20, 149-60.

3. Syril K. Que, Jeremy A., Brauer: Chronic Actinic Dermatitis. Dermatitis (2011) 22 (3), 147-154.

4. Corbett J. F: An historical review of the use of dye precursors in the formulation of commercial oxidation hair dyes. Dyes and Pigments (1999) 41, 127-36.

5. Fisher A. A.: Contact dermatitis in black patients. Cutis (1977) 20, 308-9.

6. DeLeo V. A., Taylor S. C., Belsito D. V.: The effect of race and ethnicity on patch test results. J. Am. Acad. Dermatol. (2002) 46 107-12.

7. Matulich J., Sullivan J.: A temporary henna tattoo causing hair and clothing dye allergy. Contact Dermatitis (2005) 53, 33-36.

8. DeLeo V. A.: Contact allergen of the year: p-Phenylenediamine. Dermatitis (2006) 17 (2), 53-55.
9. Ryberg K., Isaksson M., Gruvberger B.: Contact allergy to textile dyes in southern Sweden. Contact Dermatitis (2006) 54, 313-21.

10. Ryberg K., Goossens, Isaksson M.: Is Contact Allergy to Disperse Dyes and Related Substances Associated With Textile Dermatitis? Br J. Dermatol. (2009) 160(1), 107-115.

11. Seidenari S., Mantovani L., Manzini B. M.: Cross-sensitizations between azo dyes and para-amino compound. Contact Dermatitis (1997) 36, 91-96.

12. Goon A, Gilmour N. J , Basketter D. A.: High frequency of simultaneous sensitivity to Disperse Orange 3 in patients with positive patch tests to paraphenylenediamine. Contact Dermatitis (2003) $48,248-250$.

13. Picardo M., Cannistraci C., Cristaudo A.: Study on crossreactivity to the para group. Dermatologica (1990) $181,104-108$.

14. Paulsen E., Christensen L. P., Andersen K. E.: Possible crossreactivity between para-phenylenediamine and sesquiterpene lactones. Contact Dermatitis (2000) $58,120-122$

15. Wong G. A., King C. M.: Immediate-type hypersensitivity and allergic contact dermatitis due to para-phenylenediamine in hair dye. Contact Dermatitis (2003) 48, 166.

16. Sahoo B., Handa S., Penchallaiah $K$.: Contact anaphylaxis due to hair dye. Contact Dermatitis (2000) 43, 244.

17. Calzavara-Pinton P., Capezzera R., Zane C.: Lymphomatoid allergic contact dermatitis from para-phenylenediamine. Contact Dermatitis (2002) 47, 173-4.

18. Scheman A., Christina Cha., Manpreet Bhinder: Alternative Hairdye Products for Persons Allergic to Para-phenylenediamine. Dermatitis (2011) 22 (4).

Érkezett: 2013. 03. 18.

Közlésre elfogadva: 2013. 08. 26. 